\title{
Gut
}

Leading article - Molecular biology series

\section{Single gene disorders affecting the gastrointestinal tract}

In this review we discuss inherited diseases with gastrointestinal consequences that are caused by mutations in one or more genes. Familial cancers (discussed elsewhere in this series), chromosomal abnormalities, and multifactorial and congenital disorders are beyond the scope of this article.

Normal human cells are diploid - that is they carry two copies of each chromosome and hence two alleles of each gene - the exception being the $\mathrm{X}$ chromosome in men, where it is present as a single copy, along with the $\mathrm{Y}$ chromosome. The modes of inheritance of single gene disorders can be dominant (one mutant copy of the gene confers the phenotype) or recessive (both copies of the gene must carry a mutation to confer disease phenotype), and either autosomal (the gene resides on one of the 22 autosomes) or sex linked (the gene resides on a sex chromosome, usually $\mathrm{X}$ ). The precise mode of inheritance is often difficult to establish, particularly when working with small pedigrees and in diseases that show incomplete penetrance. Many diseases have a multifactorial aetiology, where one or several genes may act together with environmental factors to produce the disease state. Clinically significant single gene disorders are thought to affect about $1 \%$ of the population. ${ }^{1}$ The incidence of specific diseases varies with the population in question. Cystic fibrosis, for example, affects 1 in 2000 live births in northern Europe, and only 1 in 100000 live births in the Afro-American and Oriental populations. ${ }^{2}$ The incidence of parental consanguinity in a population will also affect the incidence of recessive genetic disease.

To characterise fully a genetic disease, it is necessary to identify the gene and its chromosomal location (gene mapping). This has been approached by both 'forward' and 'reverse' genetics. In the former, a candidate gene (for example factor VIII in haemophilia A) is purified and used to identify molecular clones of the gene. Reverse genetics, now called positional cloning, uses purely genetic techniques (linkage analysis) to identify candidate genes with no a priori knowledge of the gene product. Once a candidate gene is identified, confirmation of its involvement in the disease requires that the mutations responsible for the disease phenotype be determined (mutation detection). At this stage genetic counselling and prenatal diagnosis are possible using either linked markers in conjunction with pedigree analysis or, where possible, direct detection of the mutation. Having cloned the disease gene it is then possible to investigate the function of the gene and consider therapeutic intervention. Estimates suggest that there are between 50 and 100000 genes in the human genome, of which 2325 (excluding fragile sites and anonymous DNA segments) had been mapped by $1991 .^{3}$ Progress in human genome mapping is loosely coordinated by the Human Genome Organisation (HUGO). Current databases summarising the human genome map (the Genome Database) and inherited diseases (On-line Mendelian Inheritance in Man) are continuously updated to keep pace with rapid developments in this field.

\section{Cystic fibrosis}

Cystic fibrosis is a common cause of death in childhood and the most common inherited disease in white populations. ${ }^{4}$ It is inherited as an autosomal recessive condition, with a carrier rate of about $1 / 22$ in the UK. Cystic fibrosis has been described in non-white populations, in which it is a much rarer condition. The severity of the condition varies from mild forms (including some cases where the predominant feature is absence of the vas in men) to the more common severe forms caused by a generalised dysfunction of epithelial glands. The cause of this has now been attributed to disruption of the ion channel function of the gene affected in cystic fibrosis (see below). The lungs of patients with cystic fibrosis are vulnerable to infection by common pathogenic bacteria (as well as Pseudomonas, which is not pathogenic in healthy unaffected subjects) and the main cause of death is severe chronic infection of the lower respiratory tract. In most of those with cystic fibrosis there is a defect of pancreatic function, initially caused by a failure to produce bicarbonate and water. Pancreatic secretions become viscous causing blockage of the ductules and rupture of acini with release of enzymes. Meconium ileus occurs in about $10 \%$ of neonates with cystic fibrosis. The distal ileum becomes obstructed by proteinaceous meconium because of reduced water secretion from the pancreas and biliary system and the absence of proteolytic enzymes. Rectal prolapse is a common complication in the early years, and cystic fibrosis should be suspected whenever rectal prolapse is seen in children less than 3 years of age. ${ }^{5}$ Male patients are usually sterile because of bilateral absence or atrophy of vas. The vas deferens and associated structures are reabsorbed during embryogenesis. Fertility is also reduced in women, probably because of abnormal viscosity of the cervical mucus. Before DNA based techniques, diagnosis was established by the detection of raised sodium and chloride ions by means of a sweat test. ${ }^{6}$ Early in the course of the disease immunoreactive trypsin values are raised in blood. Although this may not be seen in infants with meconium ileus, the test is otherwise highly 
sensitive. Beyond the neonatal period blood immunoreactive trypsin values decline because of advancing pancreatic disease.

Cystic fibrosis is one of the very few genes identified solely by reverse genetic techniques, without the aid of rare chromosomal abnormalities to guide early mapping studies. In 1985 several groups reported linkage to DNA markers on chromosome 7q, and the hunt for the cystic fibrosis gene was accelerated with the identification of two markers at 7q31-32 which flanked the gene. ${ }^{7}$ Attempts by several groups to use chromosome walking to move from these markers towards the cystic fibrosis gene failed because some regions of the genome were unclonable in the vector-host systems used. This problem was overcome using chromosome jumping techniques to jump over the unclonable regions, and in 1989 the cystic fibrosis gene was identified by a group in Toronto, ${ }^{8}$ together with the most common cystic fibrosis-causing mutation. Soon afterwards, another group reported the cloning of the complete cystic fibrosis gene in a yeast artificial chromosome. ${ }^{9}$ The protein product has been named the cystic fibrosis transmembrane regulator (CFTR). The CFTR gene contains 27 exons within 250 kilobase pairs $(\mathrm{kbp})$ of genomic DNA. A messenger RNA of 6.5 kilobases is expressed in secretory epithelial tissues. A protein product of 1480 amino acids consists of a membrane-spanning domain, an adenosine triphosphate (ATP) binding domain, a hydrophilic domain (the $R$ domain) followed by another membrane spanning domain and another ATP binding domain. The function of the ATP binding domains is not known, although these regions are critical for normal function and are the target for about half of the known cystic fibrosis mutations. The most common mutation, a three base deletion at codon 508 , results in the loss of a phenylalanine residue from the first ATP binding domain. In this case the mutant gene product is not transported to the epithelial cell membrane, although this defect is temperature sensitive and transport and at least partial function does occur when the mutant gene is expressed in cell cultures grown below $30^{\circ} \mathrm{C} .{ }^{10}$ The function of CFTR seems to be that of a low conductance chloride channel regulated by cyclic adenosine monophosphate but a larger conductance outwardly rectifying chloride channel is also defective in cystic fibrosis. The gene(s) or protein(s) corresponding to the outwardly rectifying chloride channel have not yet been identified, but it may be that the CFTR is also involved in the regulation of this channel. ${ }^{11}$ The availability of a mouse model for cystic fibrosis ${ }^{12}$ may help to elucidate the pathophysiology of CFTR.

Over 200 different mutations have been described in CFTR giving rise to disease of varying severity. The common mutation, delta F508 in exon 10, is present in about $70 \%$ of northern European cystic fibrosis chromosomes. The next most common mutation (in up to $5 \%$ of cystic fibrosis chromosomes in some populations) is G551D (glycine at residue 551 is substituted by aspartate) in exon 11. Both of these mutations arise in the first ATP binding domain and are associated with a severe form of the disease in the homozygous state. Most of the other mutations are present at low levels with strong local variations in frequency. This distribution of mutations leads to difficulties in diagnosis and screening using DNA technology. One solution (which requires a priori knowledge of the types and frequencies of mutations in the test population) is to perform a two phase testing strategy in which the most common mutations are screened in the first instance, perhaps using a single test such as the multiplex ARMS test. ${ }^{13}$ With a detection rate of $80 \%$ of mutations, $80 \%$ of carriers and $64 \%$ of affected individuals will be fully characterised. Of the remaining affected cases, $32 \%$ would have a mutation detectable on one chromosome and only $4 \%$ would not have a detectable mutation on either chromosome. For those individuals incompletely charac- terised, some of the larger cystic fibrosis reference laboratories will undertake a fuller screening of CFTR. Ultimately this requires the exon by exon mutational analysis and sequencing of CFTR, or mutational analysis of CFTR mRNA. ${ }^{14}$ These are currently specialised endeavours and not offered as a diagnostic service. If the cystic fibrosis case is not the first described in a particular family, it is possible to use intragenic markers, for example a multiplex intragenic microsatellite analysis ${ }^{15}$ to determine the high risk chromosomes in parents or other relatives. Their carrier status and risks of affected children can then be established, and prenatal diagnosis offered where appropriate.

\section{Alpha $_{1}$ antitrypsin deficiency}

Alpha $_{1}$ antitrypsin deficiency was first identified in patients whose serum lacked an $\alpha_{1}$ globulin peak on protein electrophoresis. ${ }^{16}$ The serum trypsin inhibitory capacity (STIC) was also deficient, and the effect is inherited in a codominant autosomal manner. Severe $\alpha_{1}$ antitrypsin deficiency results in progressive obstructive emphysema, sometimes with the appearance of bronchial asthma. The gene frequency of the most common mutation in the UK is about $1 / 50$, almost as common as for cystic fibrosis. Alpha ${ }_{1}$ antitrypsin is synthesised predominantly in the liver but also in pancreatic islet cells, mast cells, macrophages, lymphocytes polymorphonuclear leukocytes, and platelets. Sharp ${ }^{17}$ described intrahepatocytic globules composed of the $Z$ variant of $\alpha_{1}$ antitrypsin in children with juvenile cirrhosis. Similar observations were made in adults carrying the $Z$ variant, not always in association with liver disease. ${ }^{18} 19$ The retention of the $\mathrm{Z}$ variant by the liver is thought to be caused by incomplete post translational processing of the propeptide. ${ }^{20}$ In most patients, the chest complications are far more severe than the liver disease but liver disease has been reported in about $15 \%$ of $\alpha_{1}$ antitrypsin deficient cases between 51 and 60 years of age. ${ }^{21}$

The $\alpha_{1}$ antitrypsin gene is located on chromosome 14q31$32 \cdot 1$, close to the $\alpha_{1}$ antichymotrypsin and human corticosteroid binding globulin. ${ }^{22}$ This cluster of genes, and an additional pseudogene, may have arisen by ancestral gene duplication. The $12 \cdot 2 \mathrm{kbp}$ gene has two promoters, one active in hepatocytes and the other in monocytes. ${ }^{23}$ The genes are differentially spliced in a tissue specific manner, two forms seen in monocytes contain one or two additional exons. The mature glycoprotein contains 394 amino acids and is a globular molecule. Methionine 358 and serine 359 are thought to be critical for the binding of elastase, which cleaves $\alpha_{1}$ antitrypsin at this position and is then irreversibly bound because of conformational changes in $\alpha_{1}$ antitrypsin.

There are several allelic forms of $\alpha_{1}$ antitrypsin, termed Pi (protease inhibitor) $\mathrm{M}, \mathrm{Z}, \mathrm{F}$, etc. PiM is the most common allele in all populations studies, but the frequency of the other alleles varies between different populations. High resolution isoelectric focusing has shown several new alleles. Mutations causing premature termination of the $\alpha_{1}$ antitrypsin protein or reduced synthesis are difficult to detect by protein analysis, and for these mutations, or for prenatal diagnosis, DNA analysis is the diagnostic method of choice. The inhibitory structure of $\alpha_{1}$ antitrypsin is formed by methionine at position 358 , which is an exposed loop of the molecule. A substitution of arginine at this position has been reported to result in abnormal processing and catabolism of protein $\mathrm{C}$, resulting in a mild bleeding disorder. ${ }^{2+}$ The most common severe mutation is the $\mathrm{Z}$ allele, a replacement of serine at position 342 by glutamic acid. Several methods have been described for the identification of this mutation as an aid to prenatal diagnosis, including direct sequencing of $\alpha_{1}$ antitrypsin exon $5,{ }^{25}$ allele specific PCR, ${ }^{2627}$ restriction enzyme analysis of PCR products, ${ }^{28}$ denaturing gradient gel 
analysis, ${ }^{29}$ and a chemical cleavage method, which should detect any mutation in the region of DNA analysed..$^{30}$

\section{Liver disorders}

There are several inherited metabolic disorders with significant liver pathology.

\section{IDIOPATHIC HAEMOCHROMATOSIS}

This is an autosomal recessive iron overload disease that affects patients of both sexes, usually in middle age (neonatal haemochromatosis probably represents a separate disease entity). ${ }^{36}$ In advanced forms of the disease, pronounced hepatomegaly and cirrhosis are consistent findings, although portal hypertension is rare and liver function tests may be normal. Serum iron, ferritin and transferrin saturation are increased and liver needle biopsy specimens show appreciable iron deposition in hepatocytes and Kupffer cells. Primary hepatocellular carcinoma may develop after cirrhosis, even after correction of iron overload, and is responsible for about one third of deaths in homozygotes ${ }^{32}$ emphasising the need for early detection of mild or subclinical cases through family studies. Other organs affected include the pancreas (glucose tolerance is commonly impaired) and the heart. An early sign of the disease may be hypermelanotic pigmentation of the skin, but signs of hepatic involvement before the onset of cirrhosis are rare, hence the need for family studies to detect latent or subclinical cases. Treatment (regular phlebotomies to remove $400-500 \mathrm{ml}$ of blood) shows a good response and survival is greatly increased. ${ }^{33}$ The gene locus has been mapped to the short arm of chromosome 6 near the HLA class I genes (6p21), the most significant linkage being to HLA A3. ${ }^{34}$ Estimates of the prevalence of the gene in the population have varied widely and the disease may often be undiagnosed. Absence of expression in the homozygous state is rare in the adult male, but is more frequent in premenopausal women. In the heteroxygous state, no clinical expression is observed, although biochemical markers may be raised. Simon ${ }^{35}$ suggests the gene frequency is about 0.03 , and the homozygous state less than 1 in 1000 in whites.

\section{WILSON'S DISEASE}

Wilson's disease (or hepatolenticular degeneration) is a disorder of copper metabolism characterised by juvenile, or later onset, progressive liver disease, basal ganglia disturbances, and greenish brown pigmentation of the iris (KayserFleischer rings). Penicillamine can be a very effective treatment for Wilson's disease, which is one of the few potentially treatable causes of chronic liver disease or neurodegeneration. Approximately $20 \%$ of all cases of cirrhosis presenting between the ages of 4 and 16 years are a result of this condition. ${ }^{36}$ Penicillamine treatment takes some weeks to be effective and in cases of fulminant liver failure, liver transplantation may be the only treatment option. Improvements after transplantation suggest that extrahepatic effects are secondary to overflow from the liver. ${ }^{36}$ Inheritance is by autosomal recessive mode and the incidence of homozygosity is in the range of 1 in 50000 to 1 in 100000 . Heterozygotes are asymptomatic but may have decreased serum copper and caeruloplasmin. Linkage analysis of a large inbred kindred placed the gene locus on chromosome 13, close to the esterase D gene ${ }^{37}$ and further kindreds confirm the locus at $13 q 14$, closely linked to the retinoblastoma gene and distal to the esterase $\mathrm{D}$ gene. ${ }^{38}$ The nature of the gene product is unknown, but a strong candidate gene, caeruloplasmin, is unlikely to be the culprit, it having been mapped to $3 \mathrm{q} 25 .{ }^{39}$
ARTERIOHEPATIC DYSPLASIA

Of the many structural defects of the liver, arteriohepatic dysplasia (cholestasis with peripheral pulmonary stenosis; Alagille syndrome) is considered to be an autosomal dominant condition. The syndrome is characterised by neonatal jaundice as well as changes of the heart, eyes, bones, nervous system, and facies. ${ }^{40}$

Liver histology shows few intrahepatic bile ducts. Although the gene locus is unknown, similar conditions in patients known to carry chromosomal deletions at $20 \mathrm{p} 11 \cdot 2$ suggest that the gene for arteriohepatic dysplasia may be at this site. ${ }^{41}$

\section{Diarrhoea syndromes}

Diarrhoea is a feature of several rare genetic disorders, including the secretory diarrhoeas and various inborn errors of metabolism.

\section{CHLORIDE DIARRHOEA}

Autosomal recessive chloride diarrhoea presents with watery stools containing an excess of chloride. It is present from a few weeks of age and potassium chloride is the main treatment. The disorder is caused by a defect in the ion exchange mechanisms of the intestinal brush border. Disruption of chloride/bicarbonate exchange leads to chloride diarrhoea, and a similar condition, sodium diarrhoea is caused by impaired $\mathrm{Na}+/ \mathrm{H}+$ exchange.

\section{DISACCHARIDASE DEFICIENCIES}

The disaccharidase hydrolytic enzymes (lactase, sucrase, isomaltase, and maltase) cleave disaccharides before absorption from the small intestine. Disaccharidase deficiencies cause disaccharide accumulation which encourages intestinal bacterial overgrowth; clinical manifestations include flatulence, abdominal cramps, and diarrhoea. Disaccharide intolerance $I$ is an autosomal recessive condition caused by a sucrase-isomaltase deficiency. Symptoms in homozygotes vary with the amount of ingested sucrose, but tend to be more severe in the younger child. Heterozygotes have intermediate enzyme activity, and may have mild symptoms in infancy. Peterson and Herber ${ }^{42}$ reported the incidence of sucraseisomaltase deficiency to be $\mathbf{0 . 2 \%}$ in North America, while up to $10 \%$ of the Greenland Eskimo population may be affected. ${ }^{43}$ The gene for human sucrase-isomaltase has been localised to $3 q 22-26$.

Disaccharide intolerance types II and III are respectively, congenital and adult onset lactase deficiency. Both seem to be autosomal recessive, but the relation between the conditions is unclear. The neonatal form is rare but several studies have found diarrhoea and lactose intolerance in a considerable proportion of adults, particularly in black $^{44}$ and Oriental ${ }^{45}$ populations. The lactases expressed in childhood and adult life are immunologically indistinguishable ${ }^{46}$ and McKuisick $^{47}$ suggests that adult hypolactasia may have predominated in early man and that the adult lactase polymorphism evolved in the postneolithic period when animal milk entered the diet.

\section{Pancreas}

Cystic fibrosis is the principle genetic disease of the pancreas but there are other inherited conditions with pancreatic pathology. Hereditary pancreatitis is a relatively rare autosomal dominant trait causing acute pancreatitis. Sibert ${ }^{48}$ identified 72 patients in seven families in England and Wales. Penetrance was about $80 \%$, and the onset of the disease occurred in two peaks, one in early childhood and a second at age 17 years thought to represent genetically susceptible 
persons presenting with symptoms precipitated by alcohol. Mediterranean fever may present with fever and severe abdominal pain, mimicking pancreatitis but without raised serum amylase. Symptoms also include pleurisy and synovitis and this autosomal recessive trait occurs most frequently in Armenians and Sephardic Jews. The disease has recently been genetically mapped to the short arm of chromosome 16, and linkage disequilibrium between different ethnic groups suggests the presence of at least two different mutant alleles.

\section{Intestinal defects}

There are few monogenic disorders with symptoms affecting only the intestines, most occur as part of other syndromes or are associated with chromosomal disorders. Of the many defects of gross anatomical structure of the gastrointestinal tract, only multiple intestinal atresia (described in an inbred kindred by Dallaire and Perreault ${ }^{49}$ ) seems to be transmitted as a Mendelian trait, as a result of an autosomal recessive mutation. Of the diseases presenting as functional defects, several rare familial pseudo-obstruction syndromes have been reported. Idiopathic pseudo-obstruction with megaduodenum can be transmitted as an autosomal dominant trait, whereas intestinal pseudo-obstruction caused by neuronal disease (with defective myenteric plexus) and megacystis-microcolon-intestinal hypoperistalsis syndrome are autosomal recessive traits.

In conclusion, new molecular techniques are leading to the identification of the specific genes responsible for many of the disorders described above, opening the way to molecular therapies which may lead to the amelioration or eradication of many inherited diseases.

G R TAYLOR

DNA Laboratory, Clinical Genetics Unit,

St fames's University Hospital, Leeds

Surgery, Department of Clinical Medicine,

S M FARMERY

St fames's University Hospital,

Leeds

This is the last paper in the Molecular biology series.

1 Connor JM, Ferguson-Smith MA. Essential medical genetics. 3rd Ed, Oxford Blackwell Scientific Publications, 1991

Weatherall DJ. The new genetics and clinical practice. 3rd ed. Oxford: Oxford Medical Publications, 1991.

3 McAlpine PJ, Shows TB, Boucheix C, Huebner M, Anderson WA. The 1991 catalog of mapped genes and report of the nomenclature committee. Cytogenet Cell Genet 1991; 58: 5-102.

4 McRae WM, Williamson R. In: Emery AE, Rimoin DL, eds. Principles and practice of medical genetics. Edinburgh: Churchill Livingstone, 1990: $1165-72$.

5 Swachman CH. Gastro-intestinal manifestation of cystic fibrosis. Paediatric Clinics of North America. 1975; 224: 787-805.

6 Howell DA (Chairman) Committee for a study for evaluation of testing for cystic fibrosis. 7 Paediat 1976; 88: 711-50.

7 Beaudet A, Bowcock A, Buchwald M, et al. Linkage of cystic fibrosis to two tightly linked DNA markers: joint report from a collaborative study. $A m \mathcal{F}$ Hum Genet 1986; 39: 681-93.

8 Kerem B-S, Rommens JM, Buchanan JA, et al. Identification of the cystic fibrosis gene: genetic analysis. Science 1989; 245: 1073-80

9 Anand R, Ogilvie DJ, Butler R, Riley JH, Finnear RS, Powell SJ, et al. A yeast artificial chromosome containing the cystic fibrosis locus. Genomics 1991; 9 : 124-30.

10 Denning GM, Anderson MP, Amara JF, Marshall J, Smith AE, Welsh MJ. Processing of mutant cystic fibrosis transmembrane conductance regulator is temperature-sensitive. Nature 1992; 358: 761-4

11 Egan M, Flotte T, Alfione S, Solow R, Zeitlin PL, Carter BJ, et al. Defective outwardly rectifying chloride channels by proteinase $\mathrm{A}$ corrected by insertion of CFTR. Nature 1992; 358: 581-4. 12 Higgins CF, Trezie AEO. Cystic fibrosis mice have arrived (mini review). Hum
Mol Genet 1992; 1: 459-60.

13 Ferrie RM, Schwarz MJ, Robertson NH, Vaudin S, Super M, Malone G, et al.
Development, multiplexing and application of ARMS tests for common mutations in the CFTR gene. Am F Hum Genet 1992; 51: 251-62.

14 Chalkley G, Harris A. Lymphocyte mRNA as a resource for the detection of mutations and polymorphisms in the CF gene. 7 Med Genet 1991; 28: 777-80.

15 Morral N, Estevill X. Multiplex amplification of three microsatellites within the CFTR gene. Genomics 1992; 13: 1362-4.

16 Laurell CB, Erikson S. The electrophoretic alpha ${ }_{1}$ antitrypsin deficiency. Scand F Clin Lab Invest 1963; 15: 132-40.

17 Sharp HC. Alpha -antitrypsin deficiency. Hospital Practice 1971; May: 83-96. 18 Gordon HW, Dixon J, Rogers JC, Mittman C, Leiberman J. Alpha antitrypsin accumulation in livers of emphysematous patients with alpha ${ }_{1}$ antitrypsin deficiency. Hum Pathol 1972; 3: 361-70.

19 Hultcrantz R, Menarelli S. Ultrastructural liver pathology in patients with minimal liver disease and alpha , $_{1}$-deficiency. A comparison between heterozygous and homozygous patients. Hepatology 1984; 4: 937-45.

20 Nemeth A, Strandvik B, Glaumann H. Alpha ${ }_{1}$ antitrypsin deficiency and juvenile liver disease. Ultrastructural observations compared with ligh microscopy and routine liver tests. Virchows Archiv B 1983; 44: 15-33.

21 Cox DW, Smyth S. Risk of liver disease in adults with alpha $a_{1}$-antitrypsin deficiency. Am F Med 1983; 74: 221-7.

22 Seralini GC, Berube D, Gagne D, Hammond GL. The human corticosteroid binding globulin gene is located on chromosome $14 \mathrm{q} 31-\mathrm{q} 32 \cdot 1$ near two other serine protease inhibitor genes. Hum Genet 1990; 86: 73-5.

23 Perlino E, Cortese R, Ciliberto G. The human $\alpha_{1}$ antitrypsin gene is transcribed from two different promoters in macrophages and hepatocytes. $E M B O \mathcal{Y}$ 1987; 6: 2767-81

24 Vidaud D, Emmerich J, Alhenc-Gelas M, Yuart J, Fiessinger JN, Aiach M.

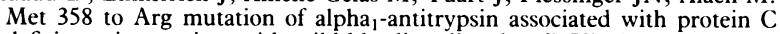
deficiency in a patient with mild bleeding disorder. 7 Clin Invest 1992; 89: 1537-43.

25 Newton CR, Kalsheker N, Graham A, Powell S, Gammack A, Riley J, et al. Diagnosis of alpha 1 -antitrypsin deficiency by enzymatic amplification of human genomic DNA and direct sequencing of polymerase chain reaction products. Nucleic Acids Res 1988; 16: 8233-43.

26 Dermer SJ, Johnson EM, Rapid DNA analysis of alpha ${ }_{1}$-antitrypsin deficiency: application of an improved method for amplifying mutated gene sequences. Lab Invest 1988; 59: 403-8.

27 Newton CR, Graham A, Heptinstall LE, Powell SJ, Summers C, Kalsheker N, et al. Analysis of any point mutation in DNA: the amplification refractory mutation system (ARMS). Nucleic Acids Res 1989; 17: 2503-16.

28 Dry PJ. Rapid detection of alpha ${ }_{1}$-antitrypsin deficiency by analysis of a PCR induced Taq restriction site. Hum Genet 1991;87: 742-4.

29 Dubel JR, Finwick R, Hejmanceik JF. Denaturing gradient gel electrophoresis of the alpha ${ }_{1}$-antitrypsin gene: application to prenatal diagnosis. Am $\mathcal{F}$ Med Genet $1991 ; 41$ : $39-43$.

30 Forrest SM, Day PJ, Cotton RG. Use of the chemical cleavage of mismatch method for prenatal diagnosis of alpha ${ }_{1}$-antitrypsin deficiency. Prenatal Diagnosis 1992; 12: 133-7.

31 Knisely AS, Magid MS, Dische MR, Cutz E. Neonatal hemochromatosis. Birth Defects 1987; 23: 75-102.

32 Bradbear RA, Bain C, Siskind V, et al. Cohort study of internal malignancy in genetic hemochromatosis and other nonalcoholic liver disease. 7 Natl Cancer Inst 1985; 75: 81-4.

33 Niederau C, Fischer R, Sonnenberg A, Stremm IW, Trampisch HJ, Strohmeyer G. Survival and causes of death in cirrhotic and non cirrhotic patients with primary hemochromatosis. N Engl F Med 1985; 313: 1256-62.

34 Simon M, Le Mignon L, Fauchet R, et al. A study of 609 haplotypes marking for the hemochromatosis gene. Am f Hum Genet 1987; 41: 89-105.

35 Simon $M$. Disorders of iron metabolism and related disorders. In: Emery EA, Rimoin DL, eds. Principles and practice of medical genetics. Edinburgh:

36 Danks DM. Disorders of copper metabolism. In: Emery AE, Rimoin DL, eds. Principles and practice of medical genetics. Edinburgh: Churchill Livingstone 990: 1771-81.

37 Frydman M, Bonne-Tamir B, Farrer LA, Conneally PM, Megazanik A, Ashbel $\mathrm{S}$, et al. Assignment of the gene for Wilson disease to chromosome 13. linkage to the esterase D locus. Proc Natl Acad Sci USA 1985; 82: 1819-21.

38 Bonne-Tamir B, Farrer LA, Frydman M, Kanaaneh H. Evidence for linkage between Wilson disease and esterase $\mathrm{D}$ in three kindreds: detection of linkage for an autosomal recessive disorder by the family study method. Genet Epidemiol 1986; 3: 201-9.

39 Yang F, Naylor SL, Lum JB, et al. Characterization, mapping, and expression of the human ceruloplasmin gene. Proc Natl Acad Sci USA 1986; 83: 3257-61.

40 Meuller A. The Allagille syndrome (arteriohepatic dysplasia) f Med Genet 1987; 24: 621-6.

41 Bryne JLB, Harrod MJE, Friedman JM, Howard-Peebles PN. del(20p) with manifestations of arteriohepatic dysplasia. Am $\mathcal{F}$ Med Genet 1986; 24: 673-8. 42 Peterson MA, Haber R. Intestinal sucrase deficiency. Transac Assō Am Physicians 1967; 80: 275-83

43 McNair A, Gudmand-Hayer E, Jarnum S, Orrild L. Sucrose malabsorption in Greenland. BMF 1972; ii: 19-21.

44 Bayliss TM, Rosensweig NS. A racial difference in incidence of lactase deficiency. A survey of milk intolerance and lactase deficiency in health adult males. FAMA 1966; 197: 968-72.

45 Huang S-S, Bayless TM. Milk and lactose intolerance in healthy Orientals. Science $1968 ; 160$ : 83-4.

46 Potter J, Ho M-W, Bolton H, Furth AJ, Swallow DM, Griffiths B. Human lactase and the molecular basis of lactase persistence. Biochem Genet 1985; 23 : 423-39.

47 McKuisick VA. Disaccharide Intolerance III. In: Mendalian inheritance in man. Baltimore: Johns Hopkins University Press, 1988: 906-7.

48 Sibert HC. Hereditary pancreatitis in England and Wales. F Med Genet 1978; 48: $618-21$.

49 Dallaire L, Perreault G. Hereditary multiple intestinal atresia. Birth Defects New York, London: Stratton Intercontinental Medical Book Corporation 1974; $\mathbf{X}(\mathrm{No} 4): 259$. 